\title{
Symptoms of posttraumatic stress disorder after exposure to biological material
}

\author{
Sintomas de transtorno de estresse pós-traumático após exposição a material biológico \\ Síntomas de transtorno de estrés post-traumático después exposición a material biológico
}

\author{
Gabriela da Cunha Januário ${ }^{1}$ \\ Priscila do Carmo Freitas de Carvalho ${ }^{1}$ \\ Juliano Teixeira Moraes ${ }^{1}$ \\ Mariana Alvina dos Santos ${ }^{2}$ \\ Elucir $\mathrm{Gir}^{3}$ \\ Silmara Elaine Malaguti Toffano ${ }^{4}$
}

\author{
1. Universidade Federal de São João Del Rei. \\ Divinópolis, MG, Brazil. \\ 2. Universidade Federal de Mato Grosso do \\ Sul. Três Lagoas, MS, Brazil. \\ 3. Universidade de São Paulo. \\ Ribeirão Preto, SP, Brazil. \\ 4. Universidade Federal do Triangulo Mineiro. \\ Uberaba, MG, Brazil.
}

Corresponding author:

Gabriela da Cunha Januário.

E-mail: gabriela_cunha92@hotmail.com

Submitted on $05 / 15 / 2017$.

Accepted on 07/30/2017.

DOI: 10.1590/2177-9465-EAN-2017-0129

\section{Abstract}

Objective: To track symptoms of posttraumatic stress disorder (PTSD) according to scores of the Impact of Event Scale-Revised (IES-R) in nursing staff exposed to accidents with biological material, from October 2014 to May 2016, in a philanthropic hospital in the state of Minas Gerais. Methods: Retrospective, descriptive study with a quantitative approach. Inferential analysis was performed using a $95 \%$ confidence interval, $p \leq 0.05$. The data were collected considering all the ethical aspects described in resolution 466/2012. Results: The majority of workers were nursing technicians (52.5\%), female $(91.8 \%)$, with a mean age of 31.4 years (SD 7.5), the majority of exposures being percutaneous (60.7\%). Of all individuals, $19.6 \%$ presented scores above 5.6, showing signs of PTSD. Individuals who had suffered accidents more than six months previously $(p=0.025)$ had significantly higher scores than those who had been exposure for less than three months. Conclusion: The study highlights the need for the use of validated instruments for the evaluation of fear, anxiety, stress, and other psychological reactions that characterize PTSD, as well as the provision of psychological care for workers exposed to biological material.

Keywords: Post-Traumatic Stress Disorder; Nursing Personnel; Occupational Exposure; Healthcare Personnel; Exposure to Biological Agents.

\section{Resumo}

Objetivo: Rastrear sintomas de Transtorno de Estresse Pós-Traumático (TEPT) segundo os escores da Escala de Impacto do Evento-Revisado em trabalhadores da equipe de enfermagem, expostos a acidente com material biológico no período de outubro de 2014 a maio de 2016 em um hospital filantrópico de Minas Gerais. Métodos: Estudo transversal, retrospectivo, descritivo, com abordagem quantitativa. A análise inferencial foi realizada utilizando-se intervalo de confiança de $95 \%$. Os dados foram coletados resguardando-se todos os aspectos éticos descritos na resolução 466/2012. Resultados: A maioria dos trabalhadores eram técnicos de enfermagem (52,5\%), do sexo feminino ( $91,8 \%$ ), com média de idade de 31,4 anos ( $D P=7,5)$. As exposições ocorreram por via percutânea $(60,7 \%)$. Do total de indivíduos, $19,6 \%$ apresentaram escores acima de 5,6 evidenciando sinais para TEPT e aqueles que haviam se acidentado há mais de seis meses tiveram escores significativamente superiores $(p=0,025)$ aos que sofreram exposição há menos de três meses. Conclusão: Um em cada cinco $(19,6 \%)$ dos trabalhadores da equipe de enfermagem que sofreram exposição ocupacional com material biológico apresentaram TEPT. Isso evidenciou a necessidade do uso de instrumentos validados para avaliação do medo, ansiedade, estresse entre outras reações psicológicas que caracterizam o transtorno e da oferta de atendimento psicológico para os trabalhadores expostos a material biológico.

Palavras-chave: Transtornos de Estresse Pós-Traumáticos; Recursos Humanos de Enfermagem; Exposição Ocupacional; Profissional da Saúde; Exposição a Agentes Biológicos.

\section{Resumen}

Objetivo: Rastrear síntomas de trastorno de estrés postraumático según los escores de la escala de impacto del evento-revisado en trabajadores del equipo de enfermería, expuestos a accidentes con material biológico en el período de octubre de 2014 a mayo de 2016 en un hospital Filantrópico de Minas Gerais. Métodos: Estudio transversal, retrospectivo, descriptivo, con abordaje cuantitativo. El análisis inferencial fue realizado utilizando intervalo de confianza del $95 \%, p \leq 0,05$. Los datos fueron recolectados resguardándose todos los aspectos éticos descritos en la resolución 466/2012. Resultados: La mayoría de los trabajadores eran técnicos de enfermería ( $52,5 \%)$, del sexo femenino $(91,8 \%)$, con una media de edad de 31,4 años $(\mathrm{DP}=7,5)$. Las exposiciones se produjeron por vía percutánea $(60,7 \%)$. Del total de individuos, el $19,6 \%$ presentó escores por encima de 5,6 evidenciando señales para TEPT y aquellos que se habían accidentado hace más de seis meses tuvieron puntuaciones significativamente superiores $(p=0,025)$ a los que sufrieron exposición hace menos de tres Los meses. Conclusión: Se evidenció la necesidad del uso de instrumentos validados para la evaluación del miedo, ansiedad, estrés entre otras reacciones psicológicas que caracterizan el trastorno de estrés postraumático y de la oferta de atención psicológica para los trabajadores expuestos a material biológico.

Palabras clave: Trastornos por Estrés Postraumático; Personal de Enfermería; Exposición Profesional; Personal de Salud; Exposición a Agentes Biológicos. 


\section{INTRODUCTION}

Occupational exposure involving biological material is characterized, according to the Ministry of Health, as sharps injuries, human bites and contact of blood/secretion with mucous membranes or non-intact skin. ${ }^{1}$ This exposure can transmit numerous pathogens, the most significant being the hepatitis $B$ virus (HBV), hepatitis $C$ virus (HCV), and human immunodeficiency virus (HIV). ${ }^{2}$

Although the transmission of blood micro-organisms is the main concern related to exposure to potentially contaminated biological material (PCBM), other harm and associated consequences, such as the fear of acquiring an infectious disease, loss of temporary or permanent functional capacity, loss of benefits, insecurity in the work, relationship or sexual activity difficulties, anxiety, Post-Traumatic Stress Disorder (PTSD), and even suicide after occupational exposure, have been observed in healthcare workers (HCWs). ${ }^{3-5}$

Different levels of stress and distress due to exposure to PCBM have been identified in some studies, ${ }^{3-6}$ which show that an event such as occupational exposure may cause suffering and anxiety, which, if not diagnosed, monitored and treated may become chronic and persistent, characterizing PTSD. ${ }^{6,7}$

Post-Traumatic Stress Disorder was included in the $3^{\text {rd }}$ Edition of the Diagnostic and Statistical Manual of Mental Disorders (DSM), published by the American Psychiatric Association $(\text { APA })^{5}(1980)$ and is characterized by the manifestation of symptoms that cause significant clinical suffering with physical, social and psychological aspects. ${ }^{8}$ It may begin within the first six months after the event [although not necessarily, since the $10^{\text {th }}$ version of the International Statistical Classification of Diseases and Related Health Problems (ICD-10) ${ }^{9}$ (2008) considers the existence of delayed-onset PTSD] and lasts longer than one month.

Studies on PTSD have been carried out with war veterans, survivors of disasters and natural catastrophes, sexual abuse victims, among many other situations that present an imminent risk of death. ${ }^{10,11}$ There are, however, few findings related the occurrence of this disorder in HCWs exposed to PCBM, ${ }^{3,6}$ which motivated this investigation.

Considering that a single occupational exposure, as well as biological risk may cause other psychological consequences, ${ }^{12,13}$ this study aimed to track PTSD symptoms according to the Impact of Event Scale-Revised (IES-R) scores in nursing staff exposed to a PCBM accident in the period from October 2014 to May 2016 in a philanthropic hospital in Minas Gerais.

\section{METHODS}

This was a cross-sectional, descriptive, retrospective, quantitative study conducted in a medium-sized philanthropic hospital located in Minas Gerais state. From October 2014 to May 2016, the research site had a population of 445 nursing staff working in direct patient care.
For the sample size calculation, a negative Pearson's correlation coefficient, $r=-0.4$, was considered between the time of occurrence of the event and the PTSD scores, for a level of significance of 0.05 and a type error II of 0.1 , resulting in an aprioristic power of $90 \%$. Using the PASS 2002 program, a minimum sample size of $n=61$ was defined.

Nursing staff exposed to biological material from October 2014 to May 2016 that reported the accident to the Engineering, Medicine and Occupational Safety Service (SESMT) of the hospital were included. Those who performed only administrative activities and those that were absent during the data collection period were excluded.

In order to identify the exposed workers, a consultation was first made of the Occupational Accident Report (OAR) and the records of the Engineering, Medicine and Occupational Safety Service (SESMT) for the workers exposed to PCBM in the period. Subsequently an active search of these was made with the intention of inviting them to participate in the study.

Data were collected using a structured instrument developed by the researcher, which included demographic and professional variables, such as professional category, work sector, length of professional experience, vaccination and occupational exposure to PCBM. The IES-R was also applied.

The IES-R is an instrument of English origin, which aims to monitor the signs and symptoms of PTSD and provide quantitative verification of a specific stressor event. ${ }^{4,14}$ The instrument was validated in Brazil, ${ }^{4}$ presenting high levels of internal consistency (Cronbach's alpha between 0.85 and 0.96). The scale is of the Likert-type, composed of 22 items, with scores ranging from 0 (not at all) to 4 (extremely), divided into three subscales: avoidance (avoidance behaviors - items 5, 7, 8, 11, 12, 13, 17 and 22), intrusion (intrusive memory - items 1, 2, 3, 6, 9,16 and 20) and hyperstimulation (anxiety - items 4, 10, 14, 15, 18, 19 and 21). ${ }^{15}$ The cutoff point established by Caiuby et al. ${ }^{4}$ (2012) in the IES-R for PTSD is 5.6.

All variables were organized into a database using the Excel program. Subsequently, the data were analyzed using the IBM SPSS version 22.0 software, through descriptive and inferential statistics.

Inferential analysis was performed by crossing the IES-R scale scores (intrusion, hyperstimulation, avoidance and total score) with the specified predictor variables (occupational category, age, type of exposure, time since occurrence of occupational exposure, source patient positive for HIV), with a $95 \%$ confidence interval, setting a significance level of $p \leq 0.05$.

The Shapiro-Wilk normality test was applied to determine whether the data of each predictor variable (occupational category, age, type of exposure, time since occurrence of occupational exposure, source patient positive for HIV) presented normal or non-normal distribution. The Kruskal-Wallis non-parametric test was then used to test whether a set of samples came from the same distribution (professional category, age, time since occupational exposure) and the Mann-Whitney 
non-parametric test was used in the two cases of independent samples (type of exposure, source patient positive for HIV). Regarding the age variable, individuals in groups 3 and 4 ( $\geq 40$ years) were combined for performance of the inferential analysis.

The study followed the principles set forth in the Declaration of Helsinki and was approved by the Research Ethics Committee (CEP) of the proposing institution (Authorization No. 1.349.749/2015) and of the Co-participant institution (Authorization No. 1.392.976/2015). The anonymity of the workers was guaranteed and all aspects of the guidelines and rules regulating research with human subjects were followed, according to Resolution CNS/CONEP No. 466/2012, of the National Health Council. The authors of the IES-R authorized its use in this study.

\section{RESULTS}

A total of 73 members of the nursing staff that had been exposed to PCBM were identified and 61 (83.5\%) met the inclusion criteria and participated in the study.

Table 1 presents the demographic and professional characteristics of all the workers who participated in the study, with these presenting a minimum age of 20 years, maximum of 57 years, mean age of 31.4 years, with standard deviation of 7.5 .

The majority of the accidents involved the percutaneous route $(60.7 \%)$, occurred during venous puncture procedure (27.9), involved blood (70.5), with the source patient serology negative for HIV and HVC (77.0). More than half were not evaluated by a specialized infectious disease service $(78.7 \%)$ and the majority of the interviewees also did not use antiretroviral therapy (86.9\%).

Using the cut-off point of 5.6 of the IES-R, established by Caiuby et al. ${ }^{4}$ (2012), the prevalence of individuals with PTSD symptoms among those investigated was 12 (19.6\%) workers in the nursing team, representing one in five.

Table 2 presents some variables related to the occupational exposure of the nursing team workers who presented PTSD symptoms, according to the IES-R scores.

Regarding the type of exposure, in the three professional categories, percutaneous was the most frequent and blood was the most frequent fluid. The majority of the individuals presented an accident time $\geq 6$ months.

Table 3 shows the intersection of the predictor variables with the IES-R subscales.

The non-parametric analysis showed that there was no significant difference $(p=0.588)$ in the IES-R total scores and professional category. This result did not confirm the hypothesis that nursing technicians and assistants would present higher scores for PTSD than nurses because of an exposition, due to their shorter time of professional training.

Another hypothesis raised in this study was that younger workers would present higher PTSD scores. The results showed a significant difference for the intrusion subscale $(p=0.04)$; in this aspect, individuals aged less than 29 years and in the age group of 30 to 39 years presented higher scores than those over the age of 40 years.
The hyperstimulation subscale did not present any significant differences in relation to age $(p=0.06)$, however, it could be considered to show a strong trend, since the value was very close to the adopted level of significance $(p \leq 0.05)$. In the analysis according to age group, there was a strong trend of significant difference among individuals under the age of 29 and those between 30 and 39 years of age compared to those aged 40 years or over $(p=0.06)$.

There was no significant difference in the scores of the avoidance subscale with age $(p=0.20)$. Regarding the total score of the scale and age, there was also no significant difference ( $p=0.06$ for both, with Bonferroni correction), however, this could be considered to show a strong trend, since the value was also very close to the adopted level of significance $(p \leq 0.05)$. In this item, there was also a strong trend of significant difference among the results of individuals aged 20 to 29 years and among those 30 and 39 years of age, in relation to those aged over 40 years ( $p=0.06$ for both, with Bonferroni correction).

As with age, it was hypothesized that the shorter the length of professional experience, the higher the PTSD scores according to the IES-R in situations of exposure to PCBM. The results indicated that there were no significant differences in relation to the length of experience in the work and the PTSD scores $(p=0.86)$.

Regarding the type of occupational exposure, the nonparametric analysis showed no significant difference between having undergone percutaneous or mucocutaneous exposure $(p=0.66)$.

Regarding the time since the accident, in the analysis of the intrusion and avoidance subscales there was a significant difference ( $p=0.01$ and $p=0.02$, respectively); thus, individuals who had been exposed for more than six months had higher scores in both subscales than those who had been exposed for less than three months. There was no statistically significant difference for the hyperstimulation scale $(p=0.31)$. Regarding the total score there was a significant difference $(p=0.02)$; the group exposed for more than six months presented higher values in the total scores than those who had been exposed for less than three months.

\section{DISCUSSION}

In the present study, it was possible to identify a relevant number of nursing staff that presented scores above the cut-off point of $5.6(12=19.6 \%)$ established in the IES-R for signs of PTSD. A similar study found in the literature, which used the same screening instrument, however, with medical professionals, showed that $12 \%$ of these workers presented evidence for the disorder after occupational exposure involving biological material. ${ }^{3}$ Another study carried out with individuals of different professional categories (drivers, HCWs, postal workers) exposed to an occupational accident involving potentially contaminated needles showed that $24 \%$ of the respondents displayed symptoms of PTSD, according to the ICD-10. ${ }^{6}$ 
Table 1. Demographic and professional characteristics of the nursing team workers exposed to PCBM $(n=61)$. Divinópolis, MG, 2014-2016.

\begin{tabular}{lccc}
\hline Variables & & $\mathbf{n}$ & $\%$ \\
\hline Sex & Female & 56 & 91.8 \\
& Male & 05 & 8.2 \\
Age & $20-29$ & 31 & 50.8 \\
& $30-39$ & 21 & 34.5 \\
& $40-49$ & 06 & 9.8 \\
Professional category & $\geq 50$ & 03 & 4.9 \\
& Nursing assistant & 07 & 11.5 \\
& Nursing technician & 22 & 36.0 \\
& Nurse & 32 & 52.5 \\
Work sector & Ward/surgical clinic & 31 & 50.8 \\
& Adult/Child ICU & 10 & 16.4 \\
& Surgical ward & 09 & 14.8 \\
& Maternity/Nursery & 04 & 6.6 \\
& Oncology & 02 & 3.3 \\
\hline
\end{tabular}

Table 2. Nursing team workers with symptoms of posttraumatic stress disorder $(n=12)$ according to the IES-R and variables related to occupational exposure to PCBM. Divinópolis, MG, 2014-2016.

\begin{tabular}{|c|c|c|c|c|c|c|c|}
\hline $\begin{array}{l}\text { Professional } \\
\text { category }\end{array}$ & $\begin{array}{c}\text { Type of } \\
\text { exposure }\end{array}$ & Fluid & $\begin{array}{l}\text { Activity performed } \\
\text { at the time of the } \\
\text { accident }\end{array}$ & $\begin{array}{c}\text { Source patient } \\
\text { serology for } \\
\text { HIV }\end{array}$ & $\begin{array}{l}\text { Post-exposure } \\
\text { prophylaxis }\end{array}$ & $\begin{array}{l}\text { Time since } \\
\text { exposure } \\
\text { (in months) }\end{array}$ & $\begin{array}{l}\text { IES-R } \\
\text { scores }\end{array}$ \\
\hline $\begin{array}{l}\text { Nursing } \\
\text { assistant }\end{array}$ & Percutaneous & Blood & Venous puncture & No & No & 06 & 7.17 \\
\hline $\begin{array}{l}\text { Nursing } \\
\text { assistant }\end{array}$ & Percutaneous & Blood & $\begin{array}{l}\text { Disposal of } \\
\text { material }\end{array}$ & No & Yes & 01 & 5.87 \\
\hline $\begin{array}{l}\text { Nursing } \\
\text { technician }\end{array}$ & Mucocutaneous & $\begin{array}{l}\text { Blood } \\
\text { secretion }\end{array}$ & PVA Clearance* & Yes & Yes & 02 & 6.78 \\
\hline $\begin{array}{l}\text { Nursing } \\
\text { technician }\end{array}$ & Mucocutaneous & $\begin{array}{c}\text { Blood } \\
\text { secretion }\end{array}$ & PVA Clearance* & No & No & 06 & 5.86 \\
\hline $\begin{array}{l}\text { Nursing } \\
\text { technician }\end{array}$ & Mucocutaneous & $\begin{array}{l}\text { Blood } \\
\text { secretion }\end{array}$ & Dressing & No & No & 17 & 6.65 \\
\hline $\begin{array}{l}\text { Nursing } \\
\text { technician }\end{array}$ & Percutaneous & Blood & $\begin{array}{l}\text { Disposal of } \\
\text { material }\end{array}$ & Unknown & Yes & 08 & 8.45 \\
\hline $\begin{array}{l}\text { Nursing } \\
\text { technician }\end{array}$ & Percutaneous & Blood & Venous puncture & No & No & 03 & 6.40 \\
\hline Nurse & Mucocutaneous & Blood & Medication & No & No & 09 & 6.26 \\
\hline Nurse & Mucocutaneous & Blood & Medication & No & No & 09 & 7.81 \\
\hline Nurse & Percutaneous & Blood & PVA puncture & No & No & 09 & 6.85 \\
\hline Nurse & Percutaneous & Blood & PVA puncture & No & No & 14 & 6.46 \\
\hline Nurse & Percutaneous & Blood & Recapping & No & No & 06 & 5.81 \\
\hline
\end{tabular}

* PVA: peripheral venous access. 
Table 3. Inferential statistical analysis of the predictive variables and IES-R scores of the nursing team workers exposed to PCBM. Divinópolis, MG, 2014-2016.

\begin{tabular}{lcccc}
\hline Variables & Intrusion & Hyperstimulation & Avoidance & Total \\
\hline Professional category & 0.594 & 0.415 & 0.543 & 0.588 \\
\hline Age & $\mathbf{0 . 0 4 8 ^ { * }}$ & 0.061 & 0.205 & 0.064 \\
Type of exposure & 0.711 & 0.415 & 0.662 & 0.668 \\
$\begin{array}{l}\text { Time since occurrence of occupational } \\
\text { exposure (in months) }\end{array}$ & $\mathbf{0 . 0 1 2 *}$ & 0.318 & $\mathbf{0 . 0 1 8 ^ { * }}$ & $\mathbf{0 . 0 2 5 ^ { * }}$ \\
\hline Source patient positive for HIV & 0.323 & 0.380 & 0.264 & 0.252 \\
\hline
\end{tabular}

${ }^{*} p \leq 0.05$; Kruskal-Wallis test.

Regarding the characteristics of the individuals, the female sex was more prevalent, this also being the case among the interviewees who had IES-R scale scores above the cutoff point for PTSD. Some studies corroborate this information and highlight sex as a risk factor for the development of the disorder, therefore, presenting a higher prevalence in women., $5,8,11,16,17$

Another finding was that women showed a tendency for increased negative affectivity, more intrusive thoughts, avoidance behaviors and greater vigilance, when compared to men, increasing the risk of developing PTSD. ${ }^{16}$ However, in the present study, the sex variable was not crossed due to the fact that the number of participants did not allow more predictor variables and due to the characteristics of the profession, which, according to Pimenta et al. ${ }^{18}$ (2013) and Fiocruz and Cofen ${ }^{19}(2015)$ is related to historical issues, with nursing being predominantly exercised by women (84.6\%), which may represent a bias.

The age group between 20 and 30 years represented more than half of the workers, as well as those with high scores in the IES-R. In the inferential analysis, this variable did not show a statistically significant difference, except for intrusive thoughts. In a study carried out with individuals that reported at least one traumatic experience during life, younger people had a greater risk for the disorder $(\mathrm{OR}=4.3) .{ }^{11}$ However, another author suggested that individuals in the 30-40 years age bracket tend to present more PTSD symptomatology, especially intrusion, when compared to younger subjects. ${ }^{16}$

Age did not present a statistically significant difference among the categories. A study carried out in Poland showed that PTSD is less present in people with higher levels of education, compared to those with lower education levels. ${ }^{17}$

Regarding the type of exposure, the percutaneous route was more common among the individuals interviewed and among those with high IES-R scores, however, this variable was not statistically significant. A study carried out in a private hospital in the state of Piauí revealed that after occupational exposure with sharps, workers experienced feelings of worry, fear of contracting HIV, hepatitis $\mathrm{B}$ or $\mathrm{C}$, and guilt due to the occurrence of the accident. ${ }^{20}$

Regarding the number of exposures in the previous year, the majority of these individuals reported one occupational accident with biological material in the period, similar to the individuals with high IES-R scores, however, the variable number of exposures/ year was not compared regarding the IES-R scores. The results of one study ${ }^{15}$ showed that professionals with greater numbers of previous experiences of disasters had higher chances of intrusive memories. Research performed with paramedics evidenced more frequent PTSD in workers who experienced several traumatic events in a short period of time $(p=0.01) .{ }^{17}$

Regarding the serological condition of the source patient, positive serology was not statistically significant for high scores in the scale evidencing PTSD, which is in agreement with another study carried out in London with resident physicians, where the scores did not reach significance when the accidents involved a high risk patient. ${ }^{3}$

The length of time since the accident happened presented an increased risk for the development of the disorder, the group with a time since the accident of more than six months showed values significantly higher than the group with less than three months of exposure $(p=0.025)$. Another study using the same instrument found no risk of PTSD in relation to the time since the injury. ${ }^{3}$

A study carried out with trauma patients sought to evaluate the course of PTSD over time after the onset of the stress event (wounds with all severity levels), and showed that, of the patients that demonstrated high IES-R scale scores over one year of monitoring, $79 \%$ persisted with the symptoms after one year, indicating that these individuals were suffering from the chronic symptoms of the disorder. ${ }^{21}$

During the interviews, at the time of data collection, some individuals reported a delay in the results of the exams of the source patient, with this situation generating an intense feeling of fear and anguish. Some authors have also shown this in their findings, reporting that waiting times for definitive blood test results cause anxiety and increase the duration of some psychiatric consequences following the exposure. This situation is considered to be as stressful as the actual occupational accident itself. ${ }^{6}$

The hospital in which the data collection was performed did not have any kind of psychology service for the care of employees. Some authors have identified that the development of PTSD is associated with a lack of social support, highlighting the need for a psychiatric service in the occupational environment to attend $\mathrm{HCW}$ s that have been affected by biological material, ${ }^{22,23}$ since 
the appearance of some psychiatric illness after occupational exposure has a major impact on the work, family relationships and sexual life of the individual. ${ }^{6}$

Although the IES-R scale and the instrument used in this study did not address issues related to the emotional reactions experienced by the individuals, during the interviews they reported feelings such as fear, insecurity and anxiety regarding the possibility of acquiring a serious illness such as HIV.Thus, this highlights the importance and necessity of further studies related to occupational accidents and the psychological approach after exposure.

\section{CONCLUSION}

The results of the present study showed that one in five (19.6\%) of the nursing staff who suffered occupational exposure to biological material presented symptoms of PTSD according to IES-R scores (cut-off point 5.6). Those in which the accident happened more than six months previously had significantly higher values in the scale, compared to those who had been exposed for less than three months.

In addition to the risk of transmission of various pathogens, occupational exposure may also cause psychological repercussions, which, if left untreated, may become chronic, including the emergence of PTSD and impairments in several areas of the life of the affected individual. There is a need for more research on this subject, with the use of validated instruments to track the symptoms, as well as improvements in the time taken for the results of the exams of the source patient. Psychological care for workers should also be provided, through the health services, aiming to identify, treat and minimize future psychological impact after occupational exposure.

\section{LIMITATIONS OF THE STUDY}

The data collected were retrospective due to the time of performance of the study and the sample was specific to a single hospital, which prevents generalization of the results. However, the findings are important for reflection regarding the psychological consequences that occupational exposure can cause in the individual and the need for further studies related to this subject and PTSD.

\section{REFERENCES}

1. Ministério da Saúde (BR). Recomendações para Terapia Anti-retroviral em adultos infectados pelo HIV. Brasília (DF): Ministério da Saúde; 2008.

2. Centers for Disease Control and Prevention - CDC. Workbook for Designing, Implementing, and Evaluating a Sharps Injury Prevention Program. Atlanta: CDC; 2008. 168p.

3. Naghavi SH, Shabestari O, Alcolado J. Post-traumatic stress disorder in trainee doctors with previous needle stick injuries. Occup Med (Lond) [Internet].2013 Jun; [cited 2016 Dec 20];63(4):260-5. Available from: https://www.ncbi.nlm.nih.gov/pubmed/23580567. DOI: 10.1093/ occmed/kqt027
4. Caiuby AVS, Lacerda SS, Quintana MI, Torii TS, Andreoli SB. Adaptação trans cultural da versão brasileira da Escala do Impacto do Evento - Revisada (IES-R). Cad Saúde Pública [Internet].2012; [cited 2016 Oct 19];28(3):597-603. Available from: http://www.scielo.br/pdf/csp/ v28n3/19.pdf

5. Forneris CA, Gartlehner G, Brownley KA, Gaynes BN, Sonis J, CokerSchwimmer $\mathrm{E}$, et al. Interventions to prevent post-traumatic stress disorder: a systematic review. Am J Prev Med [Internet].2013 Jun; [cited 2016 Nov 10];4(6):635-50. Available from: http://dx.doi.org/10.1016/j. amepre.2013.02.013

6. Green B, Griffiths EC. Psychiatric consequences of needle stick injury. Occup Med (Lond) [Internet]. 2013 Apr; [cited 2016 Dec 16];63(3):1838. Available from: https://www.ncbi.nlm.nih.gov/pubmed/23430785. DOI: $10.1093 /$ occmed/kqt006

7. Sohn JW, Kim BG, Kim SH, Han C. Mental health of health care workers who experience needle stick and sharps injuries. J Occup Health [Internet]. 2006 Nov; [cited 2016 Nov 25];48(6):474-9. Available from: https://www.jstage.jst.go.jp/article/joh/48/6/48_6_474/_article

8. American Psychiatry Association - APA. Diagnostic and Statistical Manual of Mental disorders. 5th ed. Washington: American Psychiatric Association; 2013.

9. Ministério da Saúde (BR). Organização Mundial da Saúde. CID-10. Classificação Estatística Internacional de Doenças e Problemas Relacionados à Saúde. Brasília (DF): Ministério da Saúde; 2008.

10. Tsujiuchi $T$, Yamaguchi M, Masuda K, Tsuchida M, Inomata T, Kumano $\mathrm{H}$, et al. High Prevalence of Post-Traumatic Stress Symptoms in Relation to Social Factors in Affected Population One Year after the Fukushima Nuclear Disaster. PLoS One [Internet]. 2016 Mar; [cited 2016 Dec 10];11(3):e0151807. Available from: http://dx.doi.org/10.1371/journal. pone.0151807

11. Kawakami N, Tsuchiya M, Umeda M, Koenen KC, Kessler RC; World Mental Health Survey Japan. Trauma and posttraumatic stress disorder in Japan: results from the World Mental Health Japan Survey. J Psychiatr Res [Internet]. 2014 Jun; [cited 2016 Dec 5]; 53:157-65. Available from: https://www.ncbi.nlm.nih.gov/pubmed/24572682. DOI: 10.1016/j. jpsychires.2014.01.015

12. Rymer W, Gładysz A, Filipowski H, Zubkiewicz-Zarębska A, Tumińska A, Knysz B. Risk of occupation al exposure to the HBV infection in non-clinical health care personnel. Med Pr [Internet]. 2016; [cited 2016 Nov 14];67(3):301-10. Available from: https://www.ncbi.nlm.nih.gov/ pubmed/27364104. DOI: 10.13075/mp.5893.00272

13. Samargandy SA, Bukhari LM, Samargandy SA, Bahlas RS, Aldigs EK, Alawi MA, et al. Epidemiology and clinical consequences of occupation al exposure to blood and other body fluids in a university hospital in Saudi Arabia. Saudi Med J [Internet]. 2016 Jul; [cited 2016 Oct 29]; 37(7):783-90. Available from: https://www.ncbi.nlm.nih.gov/ pubmed/27381540. DOI: 10.15537/smj.2016.7.14261

14. Caiuby AVS, Andreoli PBA, Andreoli SB. Transtorno do estresse póstraumático em pacientes de unidade de terapia intensiva. Rev Bras Ter Intensiva [Internet]. 2010 Mar; [cited 2016 Nov 17];22(1):77-84. Available from: http://dx.doi.org/10.1590/S0103-507X2010000100013

15. Guimaro MS, Caiuby AVS, Santos OFP, Lacerda SS, Andreoli SB. Sintomas de estresse pós-traumático em profissionais durante ajuda humanitária no Haiti, após o terremoto de 2010. Ciênc Saúde Coletiva [Internet]. 2013; [cited 2017 Jan 20];18(11):3175-81. Available from: http://dx.doi.org/10.1590/S1413-81232013001100008

16. Zhang Y, Ho SMY. Risk Factors of Posttraumatic Stress Disorder among Survivors after the 512 Wenchuan Earthquake in China. PLos One [Internet].2011; [cited 2016 Nov 11];6(7):e22371. Available from: https:// www.ncbi.nlm.nih.gov/pmc/articles/PMC3143136/. DOI: 10.1371/ journal.pone.0022371

17. Rybojad B, Aftyka A, Baran M, Rzońca P. Risk Factors for Posttraumatic Stress Disorder in Polish Paramedics: A Pilot Study. J Emerg Med [Internet]. 2016 Feb; [cited 2016 Oct 30];50(2):270-6. Available from: https://www.ncbi.nlm.nih.gov/pubmed/26281820. DOI: 10.1016/j. jemermed.2015.06.030 
18. Pimenta FR, Ferreira MD, Gir E, Hayashida M, Canini SRMS. Atendimento e seguimento clínico especializado de profissionais de enfermagem acidentados com material biológico. Rev Esc Enferm USP [Internet]. 2013; [cited 2016 Dec 12];47(1):198-204. Available from: http://www.scielo.br/pdf/reeusp/v47n1/a25v47n1.DOI: 10.1016/j. addbeh.2008.04.006

19. Oswaldo Cruz Foundation (FIOCRUZ); Regional Nursing Council (COFEN). New research traces nursing profile. [Internet] 2015. Available from: http://www.cofen.gov.br/pesquisa-inedita-traca-perfilda-enfermagem_31258.html

20. Lubenow JAM, Moura MEB, Nunes BMVT, Figueiredo MLF, Sales LC. Representações sociais dos acidentes com materiais perfurocortantes. Rev Latino-Am Enferm [Internet]. 2012 Nov/Dec; [cited 2017 Jan 4];20(6):1176-85. Available from: http://dx.doi.org/10.1590/S010411692012000600021
21. Haagsma JA, Polinder S, Olff M, Toet H, Bonsel GJ, van Beeck EF Posttraumatic stress symptoms and health-related quality of life: a two year follow up study of injury treated at the emergency department. BMC Psychiatry [Internet]. 2012 Jan; [cited 2017 Jan 14];12:1. Available from: https://bmcpsychiatry.biomedcentral.com/articles/10.1186/1471 $244 \mathrm{X}-12-1$

22. Carter S, Loew B, Allen E, Stanley S, Rhoades G, Markman H. Relationships between soldiers' PTSD symptoms and spousa communication during deployment. J Trauma Stress [Internet]. 2011 Jun; [cited 2016 Dec 11];24(3):352-5. Available from: https://www.ncbi. $\mathrm{nlm}$.nih.gov/pubmed/?term=Relationships+between+soldiers+PTSD+ symptoms+and+spousal+communication+during+deployment

23. Olff M. Bonding after trauma: on the role of social support and the oxytocin system in traumatic stress. Eur J Psychotraumatol [Internet] 2012; [cited 2016 Nov 15];3(1):8597. Available from: http://dx.doi. org/10.3402/ejpt.v3i0.18597 